\title{
Effect of gypsum content on soil water retention
}

Departamento de Suelo y Agua, Estación Experimental de Aula Dei, Consejo Superior de Investigaciones Científicas (CSIC), Ave. Montañana 1005, 50059 Zaragoza, Spain.

* Corresponding author

\section{SUMMARY}

Many gypsiferous soils occur in arid lands, where the water retention capacity of the soil is vital to plant life and crop production. This study investigated the effect of gypsum content on the gravimetric soil water retention curve (WRC). We analyzed calcium carbonate equivalent (CCE), equivalent gypsum content (EG), soil organic carbon content (SOC), and electrical conductivity of 43 samples collected from various horizons in soils in the Ebro Valley, NE Spain. The WRC of the fine earth was determined using the pressure-plate method (pressure heads $=0,-33,-100,-200,-500$, and $-1500 \mathrm{kPa}$ ), and the gravimetric water retention curves were fitted to the unimodal van Genuchten function. Soil gypsum content had a significant effect on water retention. Soils that had high gypsum content made WRC with higher water retention at near saturation conditions, and steeper WRC slopes. The EG threshold at which gypsum content had an effect on WRC was about $40 \%$, and EG was positively and negatively correlated with the $\alpha$ and $n$

25 parameters of the WRC, respectively.

Keywords: Calcium carbonate equivalent; gravimetric water content; Gypsic. 


\section{Introduction}

The hydrophysical properties of soil, which depend on the soil management and the soil's intrinsic textural and chemical characteristics, have a significant effect on crop growth and development. Under high annual water deficit conditions, hydro-physical properties drive infiltration and evaporation, which are the most important soil-controlled processes that influence soil water storage. Limited, irregular precipitation and high evapotranspiration constrain agricultural production on the arid lands in the Ebro Valley, NE Spain, where gypsum-rich soils are common because the moderate solubility of gypsum $\left(\mathrm{CaSO}_{4} \bullet 2 \mathrm{H}_{2} \mathrm{O}\right)$ allows it to persist as a significant component of the soil.

In some of the agricultural areas within the Central Ebro Valley, a noticeable feature is the contrasting colored patches (from tens to hundreds of square meters, and irregularly shaped), which are commonly referred to as blanqueros (white patches, WPs) and

40 fosqueros (dark patches, DPs), which have winter cereals that differ in their development (Castañeda and Moret-Fernández, 2013). WPs have soils that have high gypsum content, typically with gypsic or petrogypsic horizons (ensu Soil Survey Staff, 2014). In WP soils, often gypsum co-occurs with calcium carbonate in proportions that have to be measured by chemical analysis because their similar white color makes it difficult to assess by eye their relative proportions in the field. The parent materials -lutite, limestone, and gyprock-, and the aridic soil moisture regime are responsible for the abundance of those minerals, and WPs often occur in areas of high ground relief. In the WPs in which the gypsum -or gypsum plus calcium carbonate- content is high, mineralogical clays and organic matter are negligible. In general, gypseous soils occur in areas that receive $<400 \mathrm{~mm}$ annual rainfall (FAO, 1990), and gypsiferous materials cover about $22 \%$ of the Ebro Valley (Navas, 1983).

Primarily, hydro-physical and mechanical characteristics are the basis for the physical limitations of gypsiferous soils in supporting plant life. Very high gypsum content causes high soil mechanical impedance (Herrero and Boixadera, 2002; Moret-Fernández et al., 2013a), and reduces soil water infiltration rates (Poch et al., 1998; Moret-Fernández et al., 2011), as well as soil water retention capacity (Moret-Fernández et al., 2013a, 2013b). Moret-Fernández et al. (2011) compared the hydro-physical properties of gypseous (from 50 to $92 \%$ ) and non-gypseous soils under various soil conditions and found that the non- 
gypseous soils exhibited a more defined microstructure and retained more water at near saturation conditions than did the gypseous soils.

Despite recent research into the relationship between gypsum content and the hydrophysical properties of soils, information about the influence of gypsum content on the soil water retention curve is very limited. The purpose of this study was to investigate the effects of soil gypsum content on the water retention curve and the parameters of the van Genuchten (1980) model.

\section{Materials and methods}

Samples were collected from twelve gypsiferous soils on the Barbastro Gypsum Formation, a Late Eocene-Early Oligocene evaporitic Formation outcropping in the core of the Barbastro-Balaguer anticline (Lucha et al., 2012), and from one gypsiferous soil on the Zaragoza Gypsum Formation, a Miocene evaporitic Formation in the center of the Ebro Valley (Quirantes, 1978). The main outcrops of these Formations are depicted in Fig. 1. The mineralogy of the soils and parent materials was examined in thin sections of undisturbed blocks under a polarizing microscope.

Forty-three soil samples were collected from various horizons (Table 1). To prevent the loss of soluble salts, the soil samples were spread over plastic trays and air-dried in the lab at room temperature for several weeks. To minimize the fracturing of the gypsum crystals, the samples were crushed gently by hand using a wooden roller, and sifted by hand through a 2-mm mesh sieve. Most of the samples contained no or negligible coarse

80 fragments. Subsequent chemical and physical analyses were conducted on the fine earth.

Calcium carbonate equivalent (CCE) was measured using a Bernard calcimeter. The equivalent gypsum (EG); i.e., the total sulfates expressed as gypsum, was calculated based on the gravimetry of total sulfates after attack with hot $\mathrm{HCl}$ and precipitation as barium sulfate in a glass filtering crucible. Standard methods for the preparation of soil samples involve drying at $105^{\circ} \mathrm{C}$, which can cause the loss of the constitutional water of the gypsum crystals $\left(\mathrm{CaSO}_{4} \bullet 2 \mathrm{H}_{2} \mathrm{O}\right)$, and the artifactual production of other calcium sulfate minerals, bassanite $\left(\mathrm{CaSO}_{4} \bullet 1 / 2 \mathrm{H}_{2} \mathrm{O}\right)$ and anhydrite $\left(\mathrm{CaSO}_{4}\right)($ Steiger, 1910; Artieda et al., 2006; Herrero et al., 2009; Lebron et al., 2009), which would create spurious results in subsequent analyses; e.g., water retention capacity. Therefore, soil 
samples were dried at $40{ }^{\circ} \mathrm{C}$ (Herrero et al., 2009). Soil organic carbon (SOC) was measured using the Walkley-Black Method. Electrical conductivity was measured in extracts at a 1:5 soil-to-water weight ratio $\left(\mathrm{EC} 1: 5, \mathrm{dS} \mathrm{m}^{-1}\right)$, with $24 \mathrm{~h}$ of soil-water contact. Saturated pastes (United States Salinity Lab, 1954) were prepared and saturation percentage was recorded. The pastes were left overnight before extracts were made and electrical conductivity (ECe, $\mathrm{dS} \mathrm{m}^{-1}$ ) was measured immediately. EC measurements were converted to the standard temperature $\left(25^{\circ} \mathrm{C}\right)$. The difference between 100 and the sum of EG plus $\mathrm{CCE}$ of each sample is considered as remaining soil material, i.e., non-EG non-CCE contents.

The gravimetric water retention capacity of the samples was measured on disturbed 2mm sieved soil using the pressure-plate method at the pressure heads $(\psi)$ of $-33,-100$, $200,-500$, and $-1500 \mathrm{kPa}$. Water content of the saturated pastes was taken as the $0 \mathrm{kPa}$ pressure head. Measurements were duplicated and, if the difference was $>5 \%$, additional measurements were taken, and the results are based on the mean of the two or more replicated measurements. When the samples that came from the plates were dried, the temperature never exceeded $40^{\circ} \mathrm{C}$ (Klute, 1986). Under the assumption that residual volumetric water content is equal to zero, the SWRC Fit V.1.2 software (Seki, 2007) (http://seki.webmasters.gr.jp/swrc/) was used to fit the gravimetric water retention curve (WRC) and the corresponding effective saturation curves, $S_{e}$, to the unimodal van Genuchten (1980) model

$$
\begin{aligned}
& w(\psi)=w_{s}\left[\frac{1}{1+(\alpha \psi)^{n}}\right]^{m} \\
& S_{e}=\frac{w(\psi)}{w_{s}}
\end{aligned}
$$

where $w_{s}$ and $w(\psi)$ are the gravimetric saturated and water content at pressure head $\psi$, respectively, $n$ is the pore-size distribution parameter, $m=1-(1 / n)$ and $\alpha[\mathrm{kPa}]$ is the scale factor.

\section{Results and discussion}


EG is a valid measure of gypsum content provided that the thin sections from the soils and parent materials contain negligible or nil quantities of sulfate minerals other than gypsum (Herrero, 1991; Artieda and Herrero, 2003).

120 Fig. 2 shows EG, CCE, and the remaining soil material of the 43 samples ranked by their EG content. The non-EG or non-CCE contents in the 43 soil samples were similar if EG was $<30 \%$; however, at higher EG both CCE and the remaining soil material decreased (Fig. 2). Median SOC was $0.64 \%$, one sample had $>5 \%$ SOC, which was from an O horizon, and 34 samples had $<1.5 \%$ SOC (Table 1). Low SOC is common in arid soils. ECe and EC1:5 were not correlated, which was expected given the gypsum content of the samples. After the classification per Nogués et al. (2006), based on Soil Survey Division Staff (1993), 38 samples were non-saline to slightly saline (ECe $<4 \mathrm{dS} \mathrm{m}^{-1}$ ), three samples from deep horizons in a single pedon were moderately saline $(5.12<\mathrm{ECe}<$ $\left.7.10 \mathrm{dS} \mathrm{m}^{-1}\right)$, and one sample was very strongly saline $\left(\mathrm{ECe}=25.74 \mathrm{dS} \mathrm{m}^{-1}\right)($ Table 1$)$.

130 Gypsum content and soil salinity were not correlated, which reflected the distinction between saline and gypsum-rich soils (Herrero et al., 2009).

To assess the effect of gypsum on the WRC for disturbed soil samples, the soil samples were assigned to one of six groups based on their gypsum content $(\mathrm{EG}<10 \%, 10<\mathrm{EG}<$ $20 \%, 20<\mathrm{EG}<40 \%, 40<\mathrm{EG}<50 \%, 50<\mathrm{EG}<80 \%$, EG $>80 \%)$. In general, gypsum content had an important effect on the WRC of the soils. Soils with high EG had the highest water retention at near saturation conditions, and the steepest WRC slopes (Fig. 3). EG did not have a significant effect on $w_{\text {sat }}$ (Table 2); however, a significant and opposite influence of the gypsum content on $n$ and $\alpha$ was observed (Table 2). The $n$ and $\alpha$ values were nearly constant if EG was $<40 \%$, but at higher EG, $n$ and $\alpha$ increased and 140 decreased, respectively (Figs. 3 and 4a). That threshold, which corresponded to the EG threshold at which soil CCE decreases (Figs. 2 and 4b), would define the EG value at which gypsum begins regulating WRC.

The relationships between EG and $n$ and $\alpha$ (Fig. 4a) can be described by the exponential function

$$
y=y_{0}+a \cdot e^{(b \cdot E G)}
$$


where $y_{0}$ is the $n$ and $\alpha$ values for zero gypsum content ( $n_{0}$ and $\alpha_{0}$, respectively), and $a$ and $b$ are shape parameters (Fig. 4a). Linearization of Eq. (2),

$$
\begin{array}{ll}
\alpha^{*}=\ln \left(\alpha-\alpha_{0}\right)=-0.039(E G)-0.212 & \mathrm{R}^{2}=0.89 \\
n^{*}=\ln \left(n-n_{0}\right)=0.031(E G)-3.862 & \mathrm{R}^{2}=0.93
\end{array}
$$

150 shows that $n^{*}$ and $\alpha^{*}$ as function of EG are inversely related (Eq. 3), with a $n^{*}$ vs. $\alpha^{*}$ slope close to one (Fig. 5).

In all of the samples that had $>40 \%$ EG, gypsum was the main component and, therefore should be the main factor influencing soil behavior, which it was in the soils examined in this study. Our results are supportive of recent descriptive and taxonomical proposals for soils that have $\geq 40 \%$ gypsum. This is the case of Schoeneberger et al. (2012) that advocated the use of terms in lieu of texture, and Soil Survey Staff (2010, 2014) in (i) the separation of high-low gypsum soils, (ii) the definition of Petrogypsic, (iii) the addition of "Gypseous" to the family classification scheme, (iv) the new Hypergypsic mineralogy class, and (v) the definition of a Gypsifactic material class for the Anthropic epipedon (Soil Survey Staff, 2014). Casby-Horton et al. (2015) have reviewed some of those proposals and the analytical shortcomings for high-gypsum soils.

\section{Conclusions}

This study demonstrated that gypsum content has a significant effect on soil WRC.

165 Soils that had high gypsum content had WRC with higher water retention at near saturation conditions and steeper WRC slopes. The equivalent gypsum (EG) threshold at which gypsum influenced WRC was about $40 \%$. Increasing EG values tend to increase and decrease the $\alpha$ and $n$ van Genuchten (1980) WRC parameters, respectively. Future research should examine the effects of gypsum content on soil WRC under structured field conditions, i.e., with intact natural macroporosity, and develop physico-chemical models for the hydric behavior of gypsum particles.

\section{Acknowledgements}

This article is a result of the research project AGL2012-40100 funded by the Spanish 


\section{References}

Artieda, O., Herrero, J., 2003. Pedogenesis in lutitic Cr horizons of gypsiferous soils. Soil Sci. Soc. Am. J. 67, 1496-1506.

Artieda, O., Herrero, J., Drohan, P.J., 2006. A refinement of the differential water loss method for gypsum determination in soils. Soil Sci. Soc. Am. J. 70, 1932-1935.

Casby-Horton, S., Herrero, J., Rolong, N.A., 2015. Gypsum Soils - Their Morphology, Classification, Function, and Landscapes. Adv. Agron. 130, 231-290.

Castañeda, C., Moret-Fernández, D., 2013. Superficial color patches as a visual diagnostic criterion for agricultural management. Pedosphere 23, 40-51.

FAO, 1990. Management of gypsiferous soils. FAO Soils Bulletin 62, Rome, Italy. http://www.fao.org/docrep/t0323e/t0323e00.htm\#Contents.

Herrero, J., 1991. Morfología y génesis de suelos sobre yesos. Monografías INIA, nº 77. Madrid. 447 pp. http://hdl.handle.net/10261/84695

190 Herrero, J., Boixadera, J., 2002. Gypsic soils. pp. 635-639. In R. Lal (Ed.) Encyclopedia of Soil Science. Marcel Dekker Inc., New York. 2006, $2^{\text {nd }}$ ed., Vol I, pp. 796-799.

Herrero, J., Artieda, O., Hudnall, W.H., 2009. Gypsum, a tricky material. Soil Sci. Soc. Am. J. 73, 1757-1763.

Klute, A., 1986. Water retention: laboratory methods. In Methods of soil analysis. Part 1:

195 Physical and mineralogical method, (Ed.) A. Klute. pp. 635-662. ASA, SSSA. Madison, Wisconsin, USA.

Lebron, I., Herrero, J., Robinson, D.A., 2009. Determination of gypsum content in dryland soils exploiting the gypsum-bassanite phase change. Soil Sci. Soc. Am. J. 73, 403-411.

200 Lucha, P., Gutiérrez, F., Galve, J.P., Guerrero, J., 2012. Geomorphic and stratigraphic evidence of incision-induced halokinetic uplift and dissolution subsidence in transverse drainages crossing the evaporite-cored Barbastro-Balaguer Anticline (Ebro Basin, NE Spain). Geomorphology 171, 154-172.

Moret-Fernández, D., Bueno, G., Pueyo, Y., Alados, C.L., 2011. Hydro-physical responses of gypseous and non-gypseous soils to livestock grazing in a semi-arid region of NE Spain. Agric. Water Manage. 98, 1822-1827. 
Moret-Fernández, D., Castañeda, C., Paracuellos, E., Jiménez, S., Herrero, J., 2013a. Hydro-physical characterization of contrasting soils in a semiarid zone of the Ebro river valley (NE Spain). J. Hydrol. 486, 403-411.

210 Moret-Fernández, D., Castañeda, C., Pueyo, Y., Bueno, C.G., Herrero, J., 2013b. Hydrophysical behavior of gypseous soils under different soil management in a semiarid region of NE Spain. Arid Land Res. Manage. 27, 1-16.

Navas, A., 1983. Las litofacies yesíferas de la cuenca del Ebro. [The gypsiferous lithofacies in the Ebro Valley.] M.Sc. Thesis, IAMZ, Zaragoza, Spain. 240 pp.

215 Nogués, J., Robinson, D.A., Herrero, J., 2006. Incorporating electromagnetic induction methods into regional soil salinity survey of irrigation districts. Soil Sci. Soc. Am. J. 70, 2075-2085.

Poch, R.M., De Coster, W., Stoops, G., 1998. Pore space characteristics as indicator of soil behaviour in gypsiferous soils. Geoderma 87, 87-109.

Quirantes, J., 1978. Estudio sedimentológico y estratigráfico del Terciario continental de los Monegros. Institución Fernando el Católico. Zaragoza, Spain.

Schoeneberger, P.J., Wysocki, D.A., Benham, E.C., and Soil Survey Staff, 2012. Field book for describing and sampling soils, Vers. 3.0. Natural Resources Conservation Service, National Soil Survey Center, Lincoln, NE.

Seki, K., 2007. SWRC fit - a nonlinear fitting program with a water retention curve for soils having unimodal and bimodal pore structure. Hydrology Earth Syst. Sci. 4, 407437.

Soil Survey Division Staff, 1993. Soil survey manual. Natural Resources Conservation Service, Handbook 18. USDA. Washington, D.C.

230 Soil Survey Staff, 2010. Keys to Soil Taxonomy, $11^{\text {th }}$ ed. U.S. Department of Agriculture, Natural Resources Conservation Service, Washington, D.C.

Soil Survey Staff, 2014. Keys to Soil Taxonomy, $12^{\text {th }}$ ed. U.S. Department of Agriculture, Natural Resources Conservation Service, Washington, D.C.

Steiger, G., 1910. Note on errors in the chemical analyses of gypsum, pages 33-36 in Hess, F.L. 1910. A reconnaissance of the gypsum deposits of California. U.S. Geological Survey, Bull. 413, Washington, D.C. 
United States Salinity Laboratory Staff, 1954. Diagnosis and improvement of saline and alkali soils. Agriculture Handbook no. 60. USDA. Reprinted 1969.

van Genuchten, M.T., 1980. A closed-form equation for predicting the hydraulic conductivity of unsaturated soils. Soil Sci. Soc. Am. J. 44, 892-898. 
Table 1. Analytical data of the 43 soil samples collected at the Ebro Valley, Spain.

\begin{tabular}{|c|c|c|c|c|c|c|c|c|}
\hline \multirow[b]{2}{*}{ Pedon } & \multirow[b]{2}{*}{ Sample } & \multirow{2}{*}{$\begin{array}{c}\text { Depth interval } \\
\text { cm }\end{array}$} & \multirow[t]{2}{*}{$\mathbf{E G}^{1}$} & \multirow[t]{2}{*}{$\mathrm{CCE}^{2}$} & SOC $^{3}$ & \multirow[t]{2}{*}{$\mathrm{CCE}+\mathrm{EG}$} & $\mathrm{ECe}^{4}$ & \multirow{2}{*}{$\begin{array}{l}\text { EC1:5 } \\
n^{-1} \\
\end{array}$} \\
\hline & & & & & & & - & \\
\hline \multirow[t]{3}{*}{007} & 1 & $10-50$ & 97.7 & 2.3 & inappr. & 100 & 25.73 & 4.89 \\
\hline & 2 & $0-30$ & 0.3 & 22.5 & 0.64 & 22.8 & 2.09 & 0.36 \\
\hline & 3 & $35-47$ & 0.2 & 21.8 & 0.58 & 22.0 & 3.22 & 0.58 \\
\hline \multirow{6}{*}{011} & 4 & $69-79$ & 0.3 & 22.1 & 0.47 & 22.4 & 3.95 & 0.71 \\
\hline & 5 & $83-95$ & 3.1 & 20.4 & 0.47 & 23.5 & 5.12 & 2.00 \\
\hline & 6 & $135-144$ & 1.9 & 21.8 & 0.35 & 23.7 & 6.72 & 1.79 \\
\hline & 7 & $220-235$ & 1.5 & 22.9 & 0.47 & 24.4 & 7.1 & 1.51 \\
\hline & 8 & $0-18$ & 5.8 & 15.9 & 0.93 & 21.7 & 2.6 & 2.01 \\
\hline & 9 & $18-30$ & 8.3 & 17.9 & 0.64 & 26.2 & 2.47 & - \\
\hline \multirow[t]{4}{*}{014} & 10 & $60-70$ & 4.5 & 20.9 & 0.70 & 25.4 & 2.39 & - \\
\hline & 11 & $100-120$ & 6.6 & 22.6 & 0.47 & 29.2 & 2.43 & 2.12 \\
\hline & 12 & $200-220$ & 4.7 & 29.5 & 0.17 & 34.2 & 2.75 & - \\
\hline & 13 & $0-30$ & 1.2 & 33.4 & 1.05 & 34.6 & 2.81 & 1.05 \\
\hline \multirow{3}{*}{022} & 14 & $30-80$ & 0.6 & 32.4 & 0.52 & 33.0 & 2.41 & 0.72 \\
\hline & 15 & $80-170$ & 8.1 & 20.9 & 0.35 & 29.0 & 2.84 & 1.89 \\
\hline & 16 & $170-240$ & 13.4 & 24.7 & 0.23 & 38.1 & 3.05 & 2.32 \\
\hline \multirow{3}{*}{029} & 17 & $5-10$ & 3.2 & 32.7 & 3.90 & 35.9 & 2.71 & 2.22 \\
\hline & 18 & $1-25$ & 61.7 & 14.6 & 0.64 & 76.3 & 2.60 & 2.21 \\
\hline & 19 & $0-2$ & 0.3 & 22.9 & 11.34 & 23.2 & 2.98 & 1.34 \\
\hline \multirow{3}{*}{135} & 20 & $2-18$ & 0.4 & 32.8 & 1.86 & 33.2 & 1.70 & 0.59 \\
\hline & 21 & $18-44$ & 0.3 & 37.8 & 0.76 & 38.1 & 1.03 & 0.24 \\
\hline & 22 & $44-140$ & 41.9 & 16.9 & 0.17 & 58.8 & 2.50 & 2.07 \\
\hline \multirow[t]{2}{*}{136} & 23 & $0-2$ & 82.4 & 3.30 & 1.10 & 85.7 & 2.91 & 2.00 \\
\hline & 24 & $0-15$ & 61.1 & 6.30 & 1.10 & 67.4 & 3.78 & 2.25 \\
\hline \multirow[t]{3}{*}{137} & 25 & $18-72$ & 44.6 & 17.8 & 0.81 & 62.4 & 2.84 & 2.19 \\
\hline & 26 & $72-170$ & 34.3 & 21.4 & 0.70 & 55.7 & 2.63 & 2.19 \\
\hline & 27 & $0-16$ & 0.4 & 39.1 & 2.67 & 39.5 & 1.38 & 0.19 \\
\hline \multirow{4}{*}{138} & 28 & $20-40$ & 0.4 & 43.2 & 1.74 & 43.6 & 0.74 & 0.19 \\
\hline & 29 & $60-83$ & 0.1 & 35.9 & 2.33 & 36.0 & 1.01 & 0.26 \\
\hline & 30 & $83-170$ & 57.8 & 17.1 & 0.64 & 74.9 & 2.66 & 2.19 \\
\hline & 31 & $0-25$ & 15 & 33.3 & 1.40 & 48.3 & 2.72 & 2.21 \\
\hline \multirow[t]{4}{*}{142} & 32 & $25-88$ & 3 & 29.1 & 1.80 & 32.1 & 2.46 & 2.14 \\
\hline & 33 & $88-140$ & 8.7 & 26.2 & 1.28 & 34.9 & 2.57 & 2.23 \\
\hline & 34 & $0-25$ & ip. & 32.7 & 1.28 & 32.7 & 1.05 & 0.22 \\
\hline & 35 & $25-98$ & ip. & 34.5 & 0.58 & 34.5 & - & 0.49 \\
\hline \multirow{4}{*}{147} & 36 & $100-120$ & 4.3 & 30.2 & 0.41 & 34.5 & 3.14 & 2.13 \\
\hline & 37 & $140-160$ & 4.4 & 30.0 & 0.41 & 34.4 & 3.14 & 2.25 \\
\hline & 38 & $170-190$ & 6.2 & 37.0 & 0.35 & 43.2 & 2.95 & 1.89 \\
\hline & 39 & $210-220$ & 3.8 & 41.9 & 0.35 & 45.7 & 3.14 & 1.58 \\
\hline \multirow{2}{*}{151} & 40 & $2-27$ & 0.8 & 42.5 & 3.72 & 43.3 & 1.23 & 0.24 \\
\hline & 41 & $30-45$ & 95.9 & 5.2 & 0.58 & 99.0 & 2.48 & 2.25 \\
\hline \multirow{2}{*}{153} & 42 & $0-15$ & 26.4 & 40.0 & 2.21 & 66.4 & 2.64 & 1.57 \\
\hline & 43 & $0-15$ & 45.7 & 36.6 & 0.93 & 82.3 & 2.65 & 1.96 \\
\hline
\end{tabular}

${ }^{1}$ Equivalent gypsum; ${ }^{2}$ Calcium carbonate equivalent; ${ }^{3}$ Soil organic carbon; ${ }^{4}$ Electrical conductivity of the saturated paste extracts; ${ }^{5}$ Electrical conductivity from extracts at 1:5 soil to water weight ratio. 
Table 2. Average values of the calcium carbonate equivalent (CCE) and the $w_{\text {sat }}$, $\alpha$ and $\mathrm{n}$ parameters of the unimodal van Genuchten (1980) water retention curve for the different ranges of gypsum content (EG).

\begin{tabular}{|c|c|c|c|c|}
\hline $\mathrm{EG}(\%)$ & $\begin{array}{c}\mathrm{CCE} \\
(\%)\end{array}$ & $w_{\text {sat }}$ & $\begin{array}{c}\alpha \\
\left(\mathrm{kPa}^{-1}\right)\end{array}$ & $n$ \\
\hline $0-10$ & $28.9 \mathbf{a}$ & $46.8 \mathbf{a}$ & $0.79 \mathbf{a}$ & $1.22 \mathrm{~d}$ \\
\hline $10-20$ & $29.0 \mathbf{a}$ & $41.6 \mathbf{a}$ & $0.41 \mathbf{a}$ & $1.24 \mathrm{~cd}$ \\
\hline $20-40$ & $30.7 \mathbf{a}$ & $44.2 \mathbf{a}$ & $0.49 \mathbf{a}$ & $1.22 \mathrm{~d}$ \\
\hline $40-50$ & $23.8 \mathbf{a b}$ & $42.3 \mathbf{a}$ & $0.21 \mathbf{b}$ & $1.30 \mathrm{bc}$ \\
\hline $50-80$ & $12.7 \mathrm{bc}$ & $37.1 \mathbf{a}$ & $0.21 \mathbf{b}$ & $1.34 \mathbf{b}$ \\
\hline$>80$ & $3.7 \mathrm{c}$ & $45.4 \mathbf{a}$ & $0.11 \mathbf{b}$ & $1.63 \mathbf{a}$ \\
\hline Significance & $* * *$ & NS & $*$ & $* * *$ \\
\hline
\end{tabular}

One-way ANOVA analysis. Within each column, means followed by the same letter are not significantly 250 different at $* \mathrm{p}<0.05$; **p $<0.01 ; * * * \mathrm{p}<0.001$; NS not significantly different, by Duncan's multiple range test. 


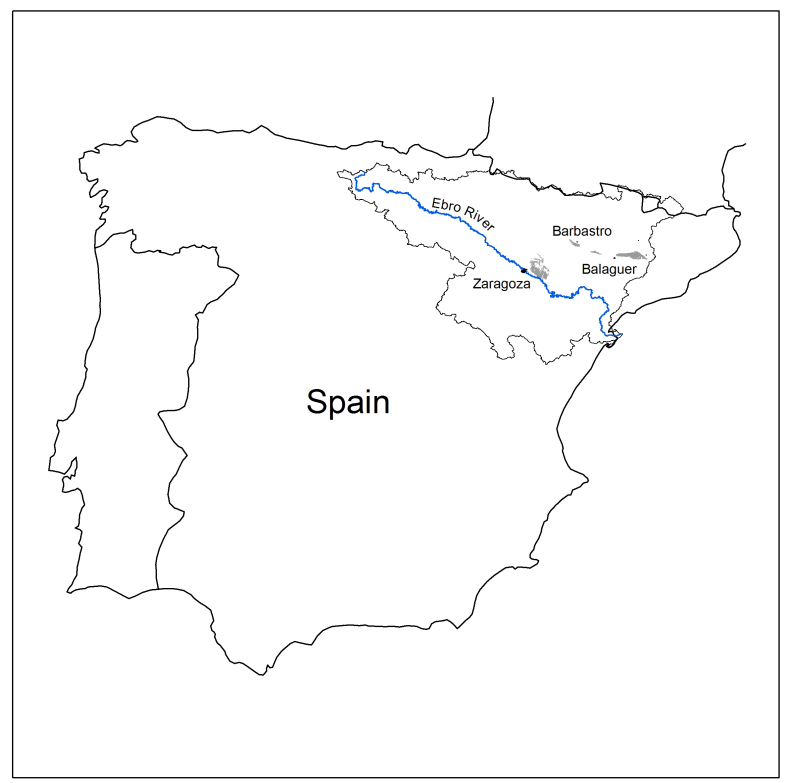

Fig. 1. Locations of the main outcrops (in grey) of the Zaragoza Gypsum Formation and the Barbastro Gypsum Formation, in the Ebro Valley where soil samples were collected from thirteen sites.

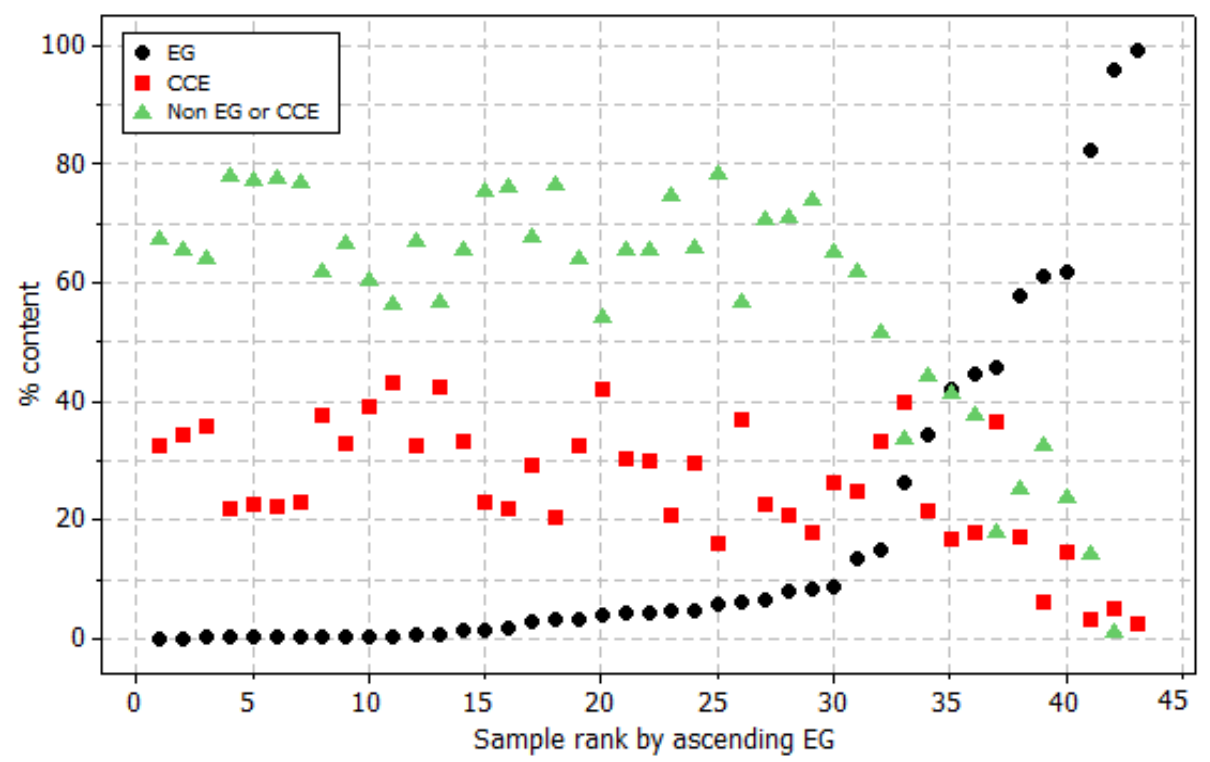

Fig. 2. Equivalent gypsum (EG), calcium carbonate equivalent (CCE), and other components (i.e., non-EG and non-CCE) in the studied 43 soil samples ranked by ascending EG. 


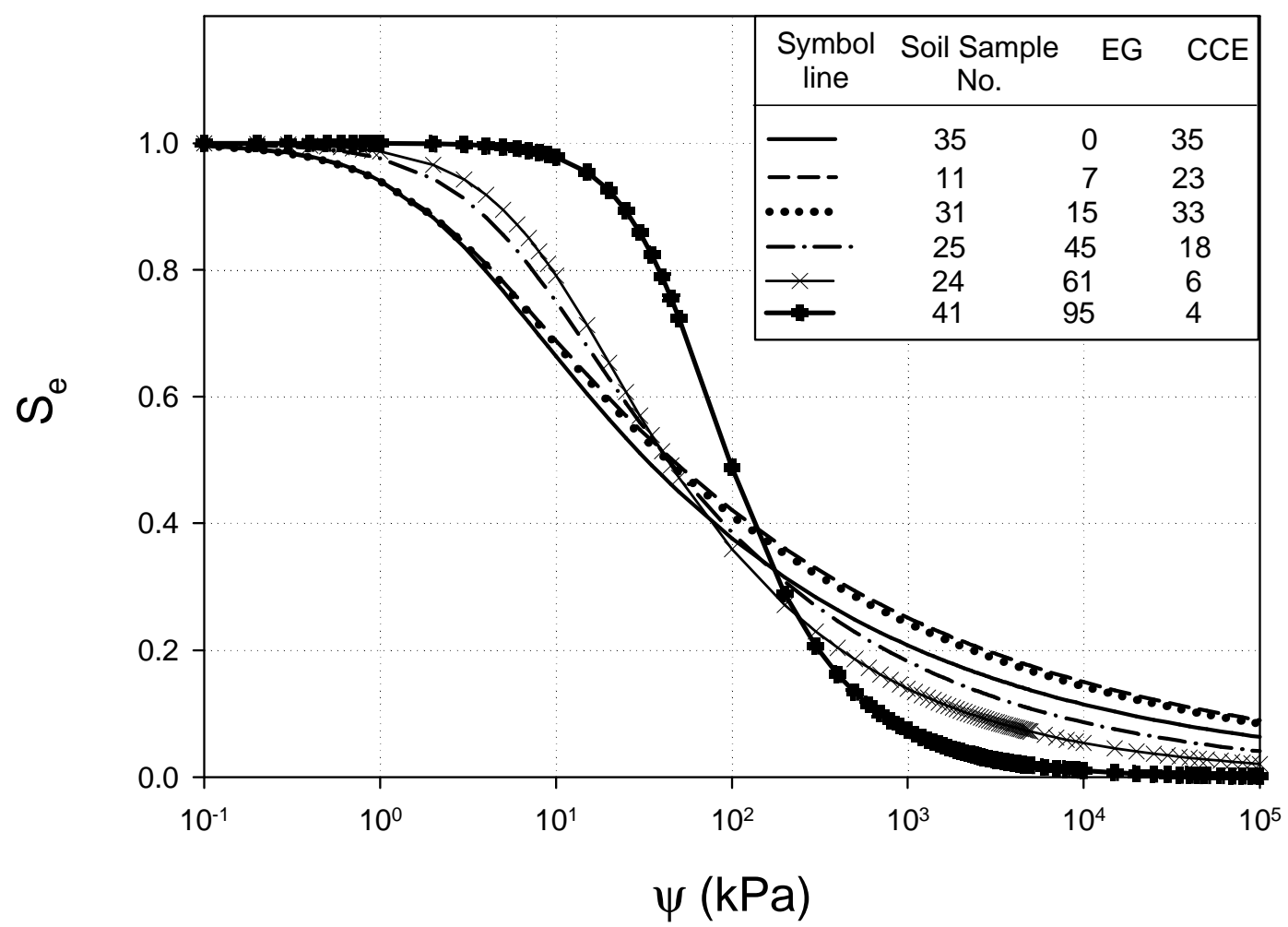

Fig. 3. Examples of effective saturation water content $\left(S_{e}\right)$ curves for six soils with different contents of gypsum (EG) and calcium carbonate (CCE). Soil samples numbers and composition are shown in Table 1. 


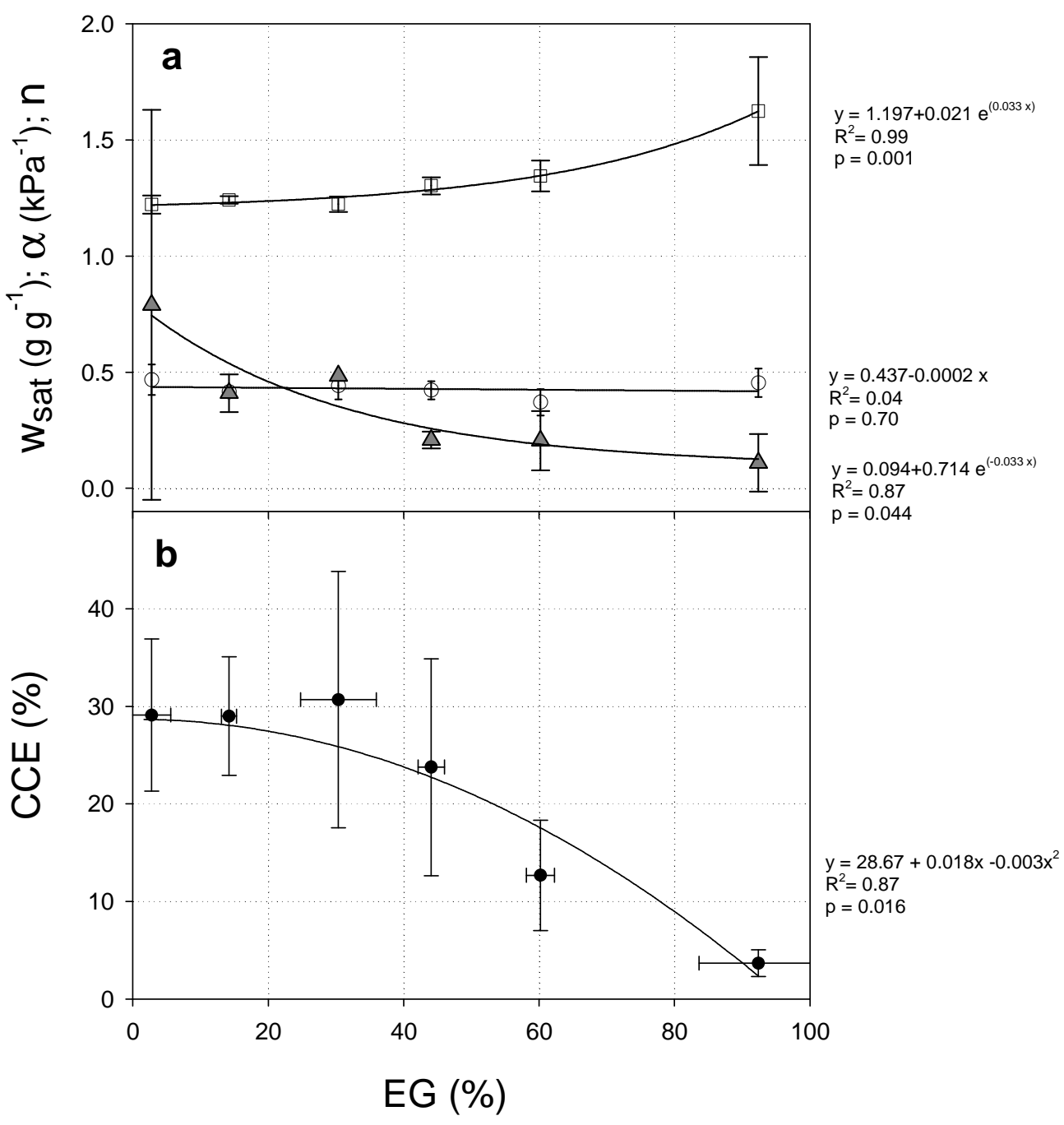

275 Fig. 4. (a) soil gravimetric water retention parameters: saturated gravimetric water content $\left(w_{\text {sat }}\right), \alpha$ and $\mathrm{n}$, versus equivalent gypsum content (EG), and (b) calcium carbonate equivalent (CCE) versus EG. For each of the six groups of samples by gypsum content $(\mathrm{EG}<10 \%, 10<\mathrm{EG}<20 \%, 20<\mathrm{EG}<40 \%, 40<\mathrm{EG}<50 \%, 50<\mathrm{EG}<80 \%$, EG>80\%), vertical bars in Fig. 4a denote the standard deviation of $w_{\text {sat }}, \mathrm{n}$, and $\alpha$, while vertical and horizontal bars in Fig. $4 \mathrm{~b}$ denote the standard deviation of CCE and EG, respectively. 


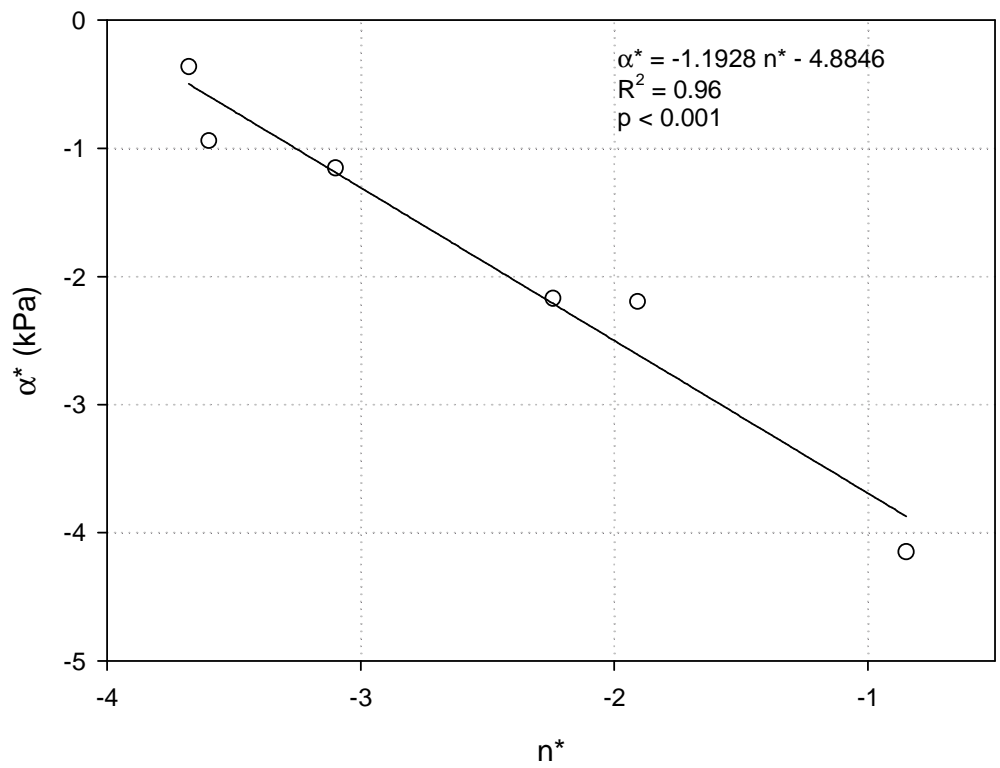

285

Fig. 5. Relationship between $\alpha^{*}$ and $n^{*}$ (Eq. 3) for the different ranges of gypsum contents of 43 soil samples collected from thirteen sites in the Ebro Valley, NE, Spain. 